\title{
Characterization in William Shakespeare's Julius Caesar
}

\author{
Esmeralda Subashi \\ $\mathrm{PhD}$, University of Tirana, Faculty of Foreign \\ Languages, English Language Department
}

\section{Abstract}

Julius Caesar, one of Shakespeare finest tragedies, has baffled readers, critics and scholars alike for centuries. It still remains one of the most read plays written by William Shakespeare and it has been part of high school curriculum in many English speaking countries world-wide. One of the most important features of it is the ambiguous and ambivalent portrayal of its characters and this paper endeavors to elaborate on the kaleidoscopic characterization in Julius Caesar by exploring its main characters with a special focus on the two tragic heroes of this play: Caesar and Brutus. Also, the paper will deal with some other important aspects of the play such as its political implications, its characteristics as a problem play and a tragedy of moral choice by building upon a wide corpus of critical criticism on Julius Caesar, and finally it will attempt to work out the play's relevance to the $21^{\text {st }}$ century readers and audiences.

Keywords: kaleidoscopic characterization, tragic hero, political play, problem play, a tragedy of moral choice, monarchy vs. republic, liberty vs. tyranny

\section{Introduction}

Julius Caesar was written between 1599 and 1601, although various critics have mentioned different years for its production. So E.K. Chambers (1930) refers to 1599, whereas M. W. MacCallum (1910, p.174) will place it in 1600 or 1601. Ernest Schanzer has called it one of Shakespeare's most perplexing plays (1955); Allardyce Nicoll regards it as one of William Shakespeare's "most difficult plays rightly to assess"; (1952, p.134) whereas Wilson Knight thinks that "to close analysis it reveals subtleties and complexities which render interpretation difficult." (1931, p. 63) The plot in a nutshell is this: the Republicans, led by Brutus and Cassius, assassinate Julius Caesar, dictator of Rome, and restore the republic. Marc Antony with Octavius, adopted son of Julius Caesar, force the Republicans to leave Rome and defeat their army in the battle at Philippi; Cassius and Brutus, in order not to fall into the hands of 
their adversaries, commit suicide one after the other; the Roman Republic eventually turns into an autocratic dictatorship.

All the events and characters of the play, with the exception of Lucius, Brutus's attendant, and some trivial details, are faithfully borrowed from Plutarch's Parallel Lives, translated from Greek into English by Sir Thomas North in 1579. Shakespeare did nothing but dramatize them, and intertwined them so beautifully that he created one of the most solid theatrical works in the world and synthesized this period of Roman history so masterfully that his brief play Julius Caesar is worth more than a dozen volumes on the topic by specialized historians.

Julius Caesar's characterization by Shakespeare has generally been criticized for not being faithful to the historical events, but at this point we have no reason to blame the greatest English playwright. It is true that the dictator of Rome was not an empty talkative braggart but, according to Plutarch's testimony, he seems to have become one in his late years as Shakespeare depicts him for us.

John Dover Wilson writes that "the play's theme is a single one, Liberty versus Tyranny" (1949, p.xxv). So, if we take this statement for granted, the question that arises is: why does this play, which is the hymn sung in praise of revolutionary liberators, bear the name of a tyrant? Critics have provided long and detailed explanations for this and since this issue is not the object of this paper we will not dwell on them. It is rather plausible that Shakespeare, as a practical Anglo-Saxon businessman, chose this title because it stood out more for advertising; on the other hand, living in the autocratic period of Elizabeth I and James I, he used this title not to appear as he was taking the side of the Republican liberators against a future king; and perhaps for this reason he observed the historical facts faithfully - which he actually did not do with his history plays so that, if the monarchists and absolutists accused him, he would blame Plutarch for that. Renowned writers before and after Shakespeare have resorted to such tricks, but no one has combined the work in such a subtle diplomatic way as to confuse not only the audience/readers of his time, but also those of modern times.

\section{Julius Caesar as a political play, a problem play and a tragedy of moral choice}

Another issue of concern for us is why Shakespeare wrote this tragedy at all, especially at this particular time of English history. In order to answer this question we will refer to the view that this play falls under the generic heading of the "political play", although many critics have denied that Julius Caesar has political implications, for example both H. J. C. Grierson (1948, pp. 91-95) and Hazleton Spencer (1940, p. 229) have argued that Shakespeare was not at all interested in political issues represented by the death of Julius Caesar, but only in character, and that the Bard remained detached from political concerns. A further radical view regarding this issue was elaborated by renowned critic Ernest Schanzer, according to whom William Shakespeare was intentionally ambiguous in portraying Julius Caesar, playing upon 
his audience's divided attitudes towards Caesar and the rightness of his assassination for pure dramatic purposes, creating in this way a sort of "problem play" like Measure for Measure. (1955, pp.297-308)

However, modern scholarship acknowledges the fact that Shakespeare was thoroughly concerned with political problems of his age, and certainly his plays reflected that concern. Thus, James Emerson Phillips argues that Julius Caesar is a vindication of absolute monarchy, represented by Caesar, against the claims of a constitutional system represented by Brutus, with Rome as the actual hero of the play (1940, pp. 172-188); whereas Virgil K. Whitaker holds that the play is a defense of absolutism (1953, pp.224-250). Whitaker also considers Julius Caesar a tragedy of moral choice, and Brutus, its protagonist, the tragic hero. The same view is further elaborated by Ernest Schanzer when he states that the main issue in the play, represented in the tragedy by Brutus's dilemma is a moral one, "consisting in the conflicting claims of the realm of personal relations and that of politics." (1963, p. 68)

We think that both views: the one referring to Julius Caesar as a political play and the other that views it as a problem play, focusing on Brutus' s tragedy as he is torn by a moral dilemma are correct. It was natural for Shakespeare to resort to the history of the assassination of Julius Caesar, a would-be dictator and tyrant by Brutus and other supporters of the Roman Republic at a time when Renaissance England's main political concern was the succession issue. The aging and childless Queen Elizabeth I, had not named her successor yet, and England was anxious about the consequences of such an omission- the civil war being the worst and most dreadful of them. So Shakespeare's timing of writing Julius Caesar at this particular perplexing time for England was perfect. On the other hand, the play is not only concerned with political issues such as absolutism, dictatorship, republicanism, liberty versus tyranny, etc., but first and foremost deals with how these public concerns interplay with personal ones, as reflected into Brutus's moral choice, his dilemma of joining the plot against Caesar and ultimately murdering him. And despite his doubts, his decision is firm: Caesar must be destroyed as Irving Ribner argues, not because he has been a tyrant but because he aspires to unlawful power, and such power must inevitably corrupt the most virtuous man and turn him to tyranny, $(1957$, p. 13) as it is shown in the 
following lines while Brutus contemplates his reasons and resolution for having Julius Caesar murdered:

And, to speak truth of Caesar,

I have not known when his affections swayed

More than his reason. But 'tis a common proof

That lowliness is young ambition's ladder,

Whereto the climber-upward turns his face;

But, when he once attains the upmost round,

He then unto the ladder turns his back,

Looks in the clouds, scorning the base degrees

By which he did ascend. So Caesar may.

Then, lest he may, prevent. And since the quarrel

Will bear no color for the thing he is,

Fashion it thus: that what he is, augmented,

Would run to these and these extremities. (II, i, 20-33)

\section{Main features of characterization in Julius Caesar}

After having referred to some modern critical interpretations of Julius Caesar, now let us turn to the major focus of this paper: characterization and its elements. Naturally, we will deal with the main axis of the play's characters: Caesar versus Brutus. In addition to focusing on the characterization features of Caesar and Brutus, we will refer to other major characters in the play as well, of considerable importance to its interpretation: Cassius, Brutus's co-conspirator and Marc Antony, Caesar's loyal friend.

Although the play is titled Julius Caesar, there is no doubt that Brutus is its protagonist as A. C. Bradley argues that "Caesar is in a sense the dominating figure in the story, but Brutus is the 'hero'." (1904, p.7) Also Anne Paolucci holds that Shakespeare's characterization of Brutus has "often puzzled readers and critics of Julius Caesar, but rarely has anyone challenged Brutus's role as the hero of the play." (1960, p. 329) Caesar-Brutus dichotomy unfolds even when it comes to the play's major theme. J. Dover Wilson is absolutely certain that the play was intended "as a bitter denunciation of the tyrant Caesar" (1949, p.xxx), while, on the contrary J. E. Phillips puts forward the idea that Julius Caesar is after all an exposé of Brutus and a resounding affirmation therefore, of the monarchical principle. (1940, pp. 172, 204)

Regardless of the contrasting views on the major concern of the play, critics, however, agree that Julius Caesar is a very ambivalent play, and it is precisely this ambivalence 
that allows for such contradictory responses to it. Thus Derek Traversi thinks that both Caesar and the conspirators who oppose him are portrayed as ambivalent figures, (1963, p.12) while Adrien Bonjour is of the opinion that every character in Julius Caesar is marked by the confusion of good and evil. (1958, p. 3)

Ernest Schanzer on the other hand argues that the enigmatic characterization of Julius Caesar is of paramount importance to the play treated in a Pirandellian manner by Shakespeare, resisting any definite outline, making us wonder that "...perhaps there is no real Cesar, that he merely exists as a set of images in other men's minds and his own?" (1963, p. 32) It is exactly this ambivalent and ambiguous portrayal of characters by Shakespeare in Julius Caesar that has led Ernest Schanzer to regard the kaleidoscopic characterization as a dramatic strategy intrinsic to the problem play: Julius Caesar is portrayed in an ambiguous way to preserve the moral dilemma which is the play's concern.

Shakespeare's characterization of Brutus has likewise often puzzled readers and critics of Julius Caesar- however rarely has anyone challenged his role as the real hero of the play, so it is clear that Brutus is not the villain of the play. In his equivocal portrayal of Brutus, Shakespeare, in exploring Brutus's personality above all is exploring the character's ambivalence and actually Shakespeare's own reaction to his protagonist is both ambiguous and ambivalent. T. S. Dorsch tries to resolve this by saying that "A man who committed Brutus's crime could not be portrayed as a wholly sympathetic character, but Shakespeare shows him as blind, not evil. And finally he buries Brutus's crime in his virtues and ends the play with Antony's tribute..." (1955, p. xliv) Brutus's blindness, his failure to grasp the true reality is his real problem, what Coleridge refers to as a principle of Shakespearean characterization: "The character himself sees himself through the medium of his character, not exactly as he is." (1960, I, p.301)

Cassius, the shrewd politician and practical realist takes advantage of the so-called Brutus's problem- he misleads Brutus into believing everything he is told in order to persuade Brutus into joining the conspiracy against Caesar. However Cassius and Brutus are radically different, although brought together by a joint cause but for different reasons and ends. They represent two political schools, two systems quite different in terms of the method that must be followed to achieve liberty from tyranny successfully. They are completely in agreement that the main task, namely the overthrow of the tyrannical regime, must be carried out by any means, without mercy and without moral scruples. They agree immediately on that without questioning the issue at all. However, after taking the major step, which in this case is the murder of Caesar, Brutus and Cassius part ways.

Cassius thinks that one should go straight to the goal taking a shortcut, with as many friends and by any means, overlooking the details, without mercy and without moral scruples, to the end. All those who might replace the tyrant must be crushed, for it is better to commit some unnecessary murder than not to commit a murder necessary 
for the common good, and therefore on this occasion to eliminate along with Caesar his close friend Marc Anthony too. Opponents should be discredited in the eyes of the people, the latter should be turned against the former with any type of propaganda, and therefore Marc Antony should not be allowed in any way to confuse the mind of common people with a word of praise for Julius Caesar. All the people that might serve for something like Cicero should be used, as many friends as possible are needed, even those won over by means of interest and bribery, because there is a risk they may side with your opponents unless you do it first. In short, to oppress tyrants, one must use the ways tyrants use to oppress the people and the defenders of their freedoms, as Marc Antony and Octavius do afterwards.

On the other hand, Brutus feels that, in order to achieve freedom successfully, one must take the safest path, with well-chosen friends and with generous means; that the people do not see the purpose, nor do they pay attention to decorum and rhetoric; they judge politicians by their friends, their tools and their work. Unnecessary bloodshed should not be instigated, because then the liberators will appear as butchers in the eyes of the people and, instead of admiration, they will attract dangerous antipathy, and this is why Brutus forbids the murder of Marc Antony and any other murder at all. The people must be enlightened to know their own good, they must be made enthusiastic about the cause of freedom, they must be inspired with faith in their liberators, and this goal is not achieved by lies and the unjust discreditation of opponents, and therefore he gives permission to Marc Antony to deliver his speech at Caesar's funeral on condition that he does not criticize those who killed Caesar. Good, loyal and disciplined friends are needed, they should be won over for the cause, for the general interest, since bad friends, recruited by means of special interests, money, bribes, desert sooner or later, once they see greater advantages elsewhere, jeopardize every step of the action and discredit the whole group in the eyes of the people.

Shakespeare depicts both systems with so much fairness, sympathy and objectivity, that it is impossible to say which of the two he prefers. Perhaps he believed that one or the other should be used, or rather an intermediate system, according to the occasion, need or people, but this is of course only a hypothesis. Either way, it can be generally said that both schools are practical and lead to success but, as history teaches us, the success of the Cassius's system, faster and easier from the very beginning, is uncertain and rarely survives afterwards, meanwhile the success of Brutus's system, slower and harder in the beginning, has solid foundations and rarely shakes or collapses afterwards.

This can be implied from this play, where we see that Cassius himself yields to Brutus's system and leadership. It can also be implied that Brutus's mistakes and shortcomings lead the Republicans to disaster, but to counterbalance this impression, Shakespeare provides us with some facts, which mainly brought about the disaster and for which neither Brutus nor his method are to blame. And in this Shakespeare 
himself follows Plutarch's lead, who regards the failure to murder Marc Antony as the first mistake and granting him permission to deliver the speech at Caesar's funeral as Brutus's second mistake but also adding very rightly that all: fate, occasion and gods have turned against the Republicans.

Up to a point Brutus and Cassius are so much alike: they are both inspired by the sacred fire, by the ideal of freedom, by the love of their country, they both feel it their supreme duty to fight to the end for the common good of the people; both are practical and hard working people; both, as heroes of classical antiquity, are of the opinion that the good brave man should either live as a man or die as a man. They are both Roman by instinct, but they are different in terms of background.

Brutus is a disciple of the Stoic philosophical school, whose teachings are almost entirely in line with Roman traditions, but he departs from it when it comes to the matter of suicide, and, as an arrogant Roman, he prefers to kill himself rather than be crushed by the triumphant chariot of tyrants in the streets of Rome. Cassius, on the other hand, is a disciple of the philosophical school of the Epicureans, which preached skepticism and the joy of life, but in real life he does the opposite: he is a militant bigot of a political ideal, for which he sacrifices every joy of life; he loves neither music, nor games, nor merriment; gloomy and dry in appearance, he seldom laughs, but studies, observes, works, struggles, suffers and dies as a martyr for a cause he does not even believe in. From this point of view he is even more tragic than Brutus.

From the same point of view, Marc Antony is a bit more tragic than Cassius. When the latter is Epicurean only in theory, Antony is Epicurean and hedonistic in theory and in practice. He is so fond of games, pleasures and women that he is considered by his friend Caesar as well as by his opponent Brutus as a man completely incapable of any serious work. But Cassius is not fooled by him. Subsequent developments prove him completely right: Marc Antony, although rotten by vices, has a streak of manhood, which requires just an opportunity to emerge. Let's notice the transformation of this man.

When Brutus and Cassius are about to assassinate Caesar, one of his friends removes Marc Antony from the Senate and quietly takes him to a party. There they party with food and drink, with women and with songs and dances. In the course of the party, Marc Anthony learns the horrific news of his friend's murder. He sobers up, wakes up, transfigures. When he goes home he is a completely different man, a heroic figure that magically emerges from the remains of a drunkard. After contemplating the situation, he prepares a plan and puts it into action immediately: he will avenge his friend's blood, or he will die next to Caesar's corpse.

Neither Cassius nor Marc Antony have moral scruples and they both make use of every means to achieve the goal. Antony falls at the feet of the Republicans, behaves like a friend to them, gets permission from Brutus to bury Julius Caesar and deliver his funeral speech, accepts their conditions and then violates them all. With the corpse 
of Julius Caesar as an ally, with the latter's toga pierced by daggers like a bloody flag in his hand, fearless when everyone is scared to death, he confuses the crowd by delivering his famous speech:

Friends, Romans, countrymen, lend me your ears.

I come to bury Caesar, not to praise him.

The evil that men do lives after them;

The good is oft interrèd with their bones.

So let it be with Caesar. The noble Brutus

Hath told you Caesar was ambitious.

If it were so, it was a grievous fault,

And grievously hath Caesar answered it.

Here, under leave of Brutus and the rest

(For Brutus is an honorable man;

So are they all, all honorable men),

Come I to speak in Caesar's funeral. (II.ii.82-93)

turning them against the Republicans and wining thus the whole war. Marc Antony from the table of pleasure goes to the funeral and from the funeral to the fight against the Republicans and then to the ultimate triumph. Thus, his Roman instinct, suddenly woken up, performs unexpected wonders and in complete contradiction to his upbringing and lifestyle.

Brutus and Cassius, twin brothers by instinct and by ideals, differ not only in terms of upbringing and system of action, but also character, temperament, and abilities. Brutus, born to be a commander, is a man of few words, of iron will, of steely nerves, patient in adversity, cold-blooded in danger, quick as lightning in action. He has disciplined his passions and knows how to control himself so completely that he does not show any external sign of what suffering and struggle takes place in his heart, as for example when he tries to hide the suicide of his beloved wife from his friends and when he restrains himself and does not weep over the corpse of the suicidal Cassius, in order not to despair his supporters prior to the final attack against Caesar's followers. Only indirectly does he let us know that there is a storm going on in his head and fire burning in his chest.

He has absolute faith in his ideal, in his system, in himself and he is so lucid, pure, uninterested, generous that not only his friends and people obey him with respect, but also his opponents are forced to acknowledge his sincerity and praise him after 
his death, as a man in every sense of the word, as Marc Antony refers to him respectfully:

This was the noblest Roman of them all. (V, v, 74)

Cassius lacks Brutus's absolute faith, composure, patience, self-control, selfconfidence, generosity and sweetness, but surpasses him in organizational propaganda and political skills, practical life experience and deep knowledge of people. Narrow-minded, fearing that the conspiracy has been discovered, if composed Brutus had not held his hand, he would have killed himself in the Senate before Caesar was murdered, and ultimately Cassius commits suicide at Philippi, because of a tragic misunderstanding, without waiting to learn what had actually happened. While Brutus is silent, endures under a tyrannical regime and waits for the favorable occasion, Cassius prefers death to submission, speaks up, works, wins over friends, prepares the next uprising, organizes the republican camp, and ambushes the tyrant on all sides. He hates tyrants with all his guts, he has no scruples, justice or mercy for them, he is ready to become twice as tyrannical as them in his methods until he crushes them and wipes them off from the face of the earth.

While both Brutus and Caesar are deceived by Marc Antony's fake appearances, Cassius recognizes in Antony's face the man who can claim the heads of all Republicans. Antony knows how to win people over. Studying people and their weaknesses, Cassius has become pessimistic, distrustful of the people whom he despises; he has lost hope, and has come to the conclusion that the new Romans should be inadvertently liberated, that they should be guided towards the path of progress. Cassius does not trust people, and they do not trust him either; people are afraid of him, his opponents are scared of him, his friends are suspicious of him. But just as Cassius knows others, he also knows himself: he knows very well what others think of him, he is aware of his own faults and the shortcomings of his system; he thinks he should be the one to lead this cause. And here lies the beauty of this idealist. For the sake of the cause, he sacrifices his personal ambition and, although he is the oldest soldier and the finest politician, although he has organized the Republicans, although he has doubts about Brutus's system, he acknowledges the latter as the leader, puts himself under Brutus's command and obeys him in all with the discipline of a Roman soldier. When he sees that Brutus's methods lead to disaster, he protests, gets angry, screams and sometimes gives the impression as if he is going to attack his friend: nothing like that. We learn how much Brutus valued this brave man, the terror of the tyrants, but softened for the companions of the ideal, when he says after Cassius' s death:

The last of all the Romans, fare thee well. (V.iii.111)

Marc Antony, on the other hand, surpasses Cassius as a master of manipulation. Antony knows how to appeal to the mob's sense of justice when he is allowed by 
Brutus to deliver his speech at Caesar's funeral. As every cunning and shrewd politician he knows how to use the exact words to achieve his ends:

For Brutus, as you know, was Caesar's angel.

Judge, 0 you gods, how dearly Caesar loved him! (III, ii, 193-4)

Brutus, so far has made a series of mistakes: has failed to lead the plot against Caesar to success; has rejected the oath; has refused to kill Marc Antony; has given permission to Marc Antony to deliver the funeral oration; but his greatest error of judgment, as Shakespeare views it, is his appeal to the rational side of the mob, while Marc Antony is aware of the irrationality of the mob and feels that the mob can be moved only by appealing to its emotions as he does through his famous speech.

\section{Conclusion}

So far we have concluded that Shakespeare has depicted both Julius Caesar and Brutus as the two great tragic heroes of his play: although Shakespeare is much intrigued by the latter and has made him the real protagonist of Julius Caesar. A final question we need to address is: If Brutus is not the villain of the play and Shakespeare has made this well-understood, then who? The answer is simple: the mob. From the very beginning of the play, Shakespeare makes it clear how irrational and fickle the mob is and he highlights that what the mob supports can never lead to any good, a theme which culminates when Marc Antony manipulates the mob as we discussed earlier.

As a final conclusion we can say that Julius Caesar is now almost unanimously (with a very few objections on the critics' side) read as a problem play which is marked by ethical, psychological and political ironies of a decidedly modern and painfully human kind. And here lies its appeal to $21^{\text {st }}$ century readers and audiences- in addition to its dealing with universal themes of tyranny, liberty, ambition, virtue; in Julius Caesar Shakespeare created two exceptional tragic characters, each bringing about his own destruction and together subjecting Rome to chaos and civil disorder. Shakespeare admires and condemns both almost equally, but his final loyalty rests with Brutus because, being a Renaissance man, a lover of personal and political freedom, the Bard would always be against tyrants and oppressors of human rights, no matter how great men the latter used to be once.

\section{References}

[1] Bonjour, Adrien. (1958). The Structure of Julius Caesar. Liverpool: Liverpool University Press.

[2] Bradley, A.C. (1904). Shakespearean Tragedy: Lectures on Hamlet, Othello, King Lear, Macbeth. London: Macmillan and Co.

[3] Chambers: E.K. (1930). William Shakespeare: A Study of Facts and Problems. 
Oxford: Clarendon Press.

[4] Coleridge, Samuel Taylor. (1960). Shakespearean Criticism, ed. Thomas M. Raysor. London: J.M. Dent.

[5] Dean, Leonard F. (1961). Julius Caesar and Modern Criticism. The English Journal, 50(7), 451-456. doi:10.2307/811198

[6] Dorsch, T. S. (1955). Julius Caesar (New Arden). Harvard University Press; London: Methuen and Co.

[7] Fortin, Rene E. (1968). Julius Caesar: An Experiment in Point of View. Shakespeare Quarterly, 19(4), 341-347. doi:10.2307/2868490

[8] Grierson, H.J.C. (1948). Cross Currents in English Literature of the XVIIth Century. London: Chatto \& Windus.

[9] Knight, Wilson G.; (1931). The Imperial Theme: Further Interpretations of Shakespeare's Tragedies Including the Roman Plays. London: Routledge.

[10] MacCallum, M. W. ( 1910) Shakespeare's Roman plays. London: Macmillan \&Co.

[11] Nicoll, Allardyce (1952). Shakespeare. London: Oxford University Press.

[12] Palmer, John. (1970). Tragic Error in Julius Caesar. Shakespeare Quarterly, 21(4), 399-409.doi:10.2307/2868424

[13] Paolucci, Anne. (1960). The Tragic Hero in Julius Caesar. Shakespeare Quarterly, 11(3), 329-333. doi:10.2307/2867298

[14] Phillips, J. E. (1940). The State in Shakespeare's Greek and Roman Plays. New York: Columbia University Press.

[15] Ribner, Irving. (1957). Political Issues in Julius Caesar. The Journal of English and Germanic Philology, 56(1), 10-22.

[16] Schanzer, Ernest. (1955). The Problem of Julius Caesar. Shakespeare Quarterly, 6(3), 297-308. doi:10.2307/2866616

[17] Schanzer, Ernest. (1955). The Tragedy of Shakespeare's Brutus. ELH, 22(1), 1-15. doi:10.2307/2872001

[18] Schanzer, Ernest. (1963). The Problem Plays of Shakespeare. London: Routledge and Kegan Paul PLC.

[19] Shakespeare, William. (1954). Julius Caesar in The Complete Works of William Shakespeare, ed. W. J. Craig. London: Oxford University Press.

[20] Spencer, Hazleton. (1940). The Life and Art of William Shakespeare. New 
York: Harcourt, Brace \& Company.

[21] Traversi, Derek. (1963). Shakespeare- The Roman Plays. London: Hollis \& Carter.

[22] Whitaker, Virgil K. (1965). The Mirror Up to Nature: The Technique of Shakespeare's Tragedies. San Marino, CA: Huntington Library.

[23] Wilson, J. Dover. (1949). Introduction to Julius Caesar. New Cambridge Shakespeare. London: Cambridge University Press. 